\title{
DORONGAN MENCARI SENSASI \\ DAN PERILAKU PENGAMBILAN RESIKO PADA MAHASISWA
}

Ratna Syifa'a Rachmahana

\begin{abstract}
This research aimed at finding correlation between sensation seeking and risk taking behavior among students. This study was done by experimental method. It was hypothesis that was a positive correlation between level of sensation seeking and risk taking behavior.

Data were collected from 79 students in faculty of Psychology from Islamic University of Indonesia. The students participated in ring tosses experiment, adapted from Sorrentino (1992). Before experiment, students had completed sensation seeking scale.

The relationship between level of sensation seeking and risk taking behavior was determined by product moment analysis. The result of the research was that sensation seeking correlated with risk taking behavior ( $r=.226 ; p=0.045)$.
\end{abstract}

Key Words : Sensation Seeking, Risk Taking Behavior.

\section{PENGANTAR}

Setiap orang dapat dipastikan akan berhadapan dengan berbagai permasalahan dalam perjalanan kehidupan. Suatu saat, permasalahan yang dihadapi tergolong ringan. Saat lain, permasalahan yang dihadapi menuntut proses pemecahan masalah yang cenderung kompleks dan tak jarang membutuhkan banyak pertimbangan. Seseorang terkadang dituntut untuk menentukan pilihan-pilihan yang mengandung risiko bagi dirinya. Hal tersebut merupakan hal yang wajar dalam kehidupan individu.

Permasalahan pengambilan risiko ini menjadi hal penting pada masa remaja dan masa dewasa awal. Kesalahan dalam proses pengambilan risiko akan membawa dampak yang sangat berarti dalam kehidupan selanjutnya. Pandangan Haditono dkk.
(1999) mempertegas hal ini, bahwa dalam masa remaja dan masa dewasa awal merupakan masa-masa yang kritis dalam proses kehidupan seseorang. Pada masa tersebut, individu berusaha untuk mendapatkan jati dirinya. Secara logika, dalam masa tersebut, individu akan berusaha untuk menentukan pilihan dalam kehidupan ini, sehingga eksistensi dirinya dapat dilihat oleh orang lain. Permasalahannya, takjarang dalam penentuan pilihan atas jati dirinya tersebut mengandung berbagai risiko.

Mahasiswa sebagai generasi penerus bangsa diharapkan menunjukkan kesiapan untuk menghadapi segala perubahan. Ini berarti pada diri mahasiswa juga dituntut untuk memiliki keberanian untuk mengambil risiko. Dengan keberanian ini, seseorang 
tidak akan mudah mencari " kambing hitam " manakala dihadapkan pada suatu masalah, atau dengan kata lain lebih bertanggung jawab atas pilihan yang telah diyakininya atau kejadian yang menimpanya.

Dalam proses pengambilan risiko, tidak semuanya berarti negatif atau tidak efektif. Dalam situasi-situasi tertentu misalnya kondisi yang sangat genting, kecepatan bereaksi dengan mempertimbangkan segala konsekuensi, memaksa seseorang untuk segera memilih alternatif yang terbaik. Dengan demikian kemampuan pengambilan risiko sangat penting dimiliki oleh seseorang, terutama berkaitan dengan perubahan situasi dan kondisi yang sangat cepat terjadi, seperti saat ini.

Dalam era globalisasi seperti saat ini, perubahan sangat cepat terjadi. Dari hari ke hari, perubahan demi perubahan dapat dirasakan. Salah satu hal yang menonjol adalah masalah kemajuan teknologi informasi. Kemajuan tersebut membawa dampak yang sangat luas. Apa yang terjadi hari ini di suatu belahan bumi dapat diketahui dengan cepat di belahan bumi yang lain. Dengan demikian, kemajuan di suatu negara dapat ditiru dan dijadikan contoh bagi negara lain. Fenomena demikian tentu saja menuntut kemampuan seseorang untuk beradaptasi dengan cepat dan terus-menerus tanpa henti. Individu yang kurang memiliki kemampuan beradaptasi dapat dipastikan akan ketinggalan jaman, yang akhirnya akan tidak mampu bersaing dalam segala bidang.

Ketangguhan untuk siap menanggung risiko apapun sangat erat kaitannya dengan kemampuan di atas. Sebagai calon pemimpin bangsa, mestinya mahasiswa memilikinya. Akan tetapi fenomena yang ada menunjukkan hal lain. Banyak mahasiswa yang masih kurang responsif dalam menanggapi perubahan, cenderung manja dan kurang siap menerima tantangan. Hampir sebagian besar lulusan perguruan tinggi mendambakan menjadi salah satu unsur dalam sebuah organisasi yang sudah mapan, atau dengan kata lain sangat sedikit yang berpikir untuk merencanakan masa depan dengan membuka usaha secara mandiri. Risiko kegagalan dalam langkah berwirausaha adalah sesuatu yang ditakuti oleh sebagian besar dari mereka. Kesediaan menerima tantangan dengan menanggung segala risiko yang ditimbulkan disebut sebagai dorongan pencarian sensasi.

Dorongan pencarian sensasi dikenal dalam ilmu psikologi dengan istilah sensation seeking. Istilah ini dipopulerkan oleh Zuckerman (1982), yang mendefinisikannya sebagai suatu bentuk dorongan pada diri manusia untuk mencari berbagai macam sensasi dan pengalaman baru yang luar biasa (atau mungkin agak aneh) dan kompleks, serta bersedia mengambil risiko fisik, sosial, hukum dan finansial demi pengalaman tersebut.

Dorongan pencarian sensasi sebetulnya ada pada setiap orang, namun berbeda tingkatannya. Hal ini semata-mata disebabkan oleh perbedaan tingkat kebutuhan akan peningkatan stimulasi (increase stimulation) yang ada pada diri orang tersebut.

Selanjutnya dijelaskan oleh Zuckerman (dalam Smith, dkk., 1992) 
bahwa ada hubungan yang positif antara dorongan pencarian sensasi dengan pengambilan risiko secara fisik, penggunaan obat-obatan, kompleksitas pilihan dan sukarelawan dalam eksperimen-eksperimen psikis yang menjanjikan berbagai bentuk pengalaman baru.

Berpijak dari uraian di atas, nampak sekali kaitan antara perilaku pengambilan risiko dan dorongan pencarian sensasi. Hanya saja bagaimana bentuk hubungan yang ada masih belum jelas. Apabila individu memiliki dorongan mencari sensasi yang tinggi, apakah itu berarti lebih baik dalam pengambilan risikonya ? Pertanyaan itulah yang hendak dicari jawabannya lewat penelitian ini.

\section{TELAAH PUSTAKA}

\section{Perilaku Pengambilan Resiko.}

Perilaku pengambilan risiko (risk taking behavior) adalah berbagai aktivitas yang memungkinkan membawa sesuatu yang baru atau cukup berbahaya yang menimbulkan kecemasan pada hampir sebagian besarmanusia (Levenson, 1990). Keputusan individu untuk mengambil tindakan yang berisiko ini didasari oleh adanya kemauan dan atau keberanian (Larasati, 1993). Individu yang berani mengambil resiko, dalam kondisi gagal akan selalu menerima konsekuensi atau akibat pilihan pekerjaannya, tanpa berusaha mencari kambing hitam.

Dalam kajian-kajian Psikologi Kognitif, perilaku pengambilan risiko berkaitan erat dengan pembuatan keputusan. Kahneman \& Tversky's mengenalkan istilah Teori Prospek untuk membuktikan adanya pengaruh res- pons seseorang terhadáp problema yang mengakibatkan adanya perbedaan sikap terhadap nilai dan resiko. Selanjutnya teori ini memberikan implikasi bahwa dengan memanipulasi formulasi suatu problem atau framing, orang dapat dimotivisir untuk menunjukkan tingkah laku tertentu, yakni apakah ia akan cenderung mengambil atau menghindari risiko (Hastjarjo, 1991).

Menurut Slovic dan kawankawan (1987), secara umum ada tiga kelompok jenis risiko yang dipersepsi manusia dalam kehidupan sehari-hari, yaitu risiko aktivitas sehari-hari (misalnya mengemudi, merokok); risiko akibat penggunaan suatu zat ; serta risiko akibat kemajuan teknologi (misalnya penggunaan sinar $\mathrm{X}$ ).

Perilaku pengambilan risiko dapat bersifat fisik, sosial maupun keduanya. Pengambilan risiko fisik misalnya pada pemanjat tebing dan pemadam kebakaran untuk tingkat tinggi, berenang atau mengendarai kendaraan untuk tingkat sedang, ataupun bahkan perilaku sehari-hari yang menimbulkan risiko-risiko secara fisik yang relatif kecil. Pada risiko yang bersifat sosial bisa ditemukan dalam perilaku-perilaku yang menimbulkan risiko secara sosial, misalnya kurangnya privacy jika menjadi pejabat, adanya jarak sosial, bahkan sampai dengan dikucilkan dalam pergaulan.

Tak dapat dipungkiri bahwa sebetulnya tiap orang memiliki alasan yang berbeda untuk mengambil risiko. Sebagai contoh, keberanian para pemanjat tebing dalam mengambil risiko tentu sangat berbeda dengan pengambilan risiko oleh para pecandu obat-obatan. 
Lebih lanjut Levenson (1990) membagi tiga kelompok para pengambil risiko dengan berdasar pada karakteristik kepribadian dan orientasi sosial, yakni :

a. Kelompok pengambil risiko anti sosial, misalnya pada penghuni unit penyalahgunaan obat-obatan yang memiliki gaya hidup tersendiri dan umumnya dilakukan dengan tujuan mencari sensasi. Kelompok ini biasanya cenderung bersifat impulsif.

b. Kelompokpengambil risiko pro-sosial, seperti polisi, pemadam kebakaran, dan lain-lain. Pengambilan resiko yang dilakukan dapat tergambar dari keberaniannya menolong orang lain, meskipun terkadang mereka melakukannya dalam rangka tugas rutin dan tanggung jawab yang dipikul oleh jabatan tersebut.

c. Kelompok pengambil risiko petualang, contohnya pemanjat tebing. Perilaku pengambilan risiko yang dilakukan individu sudah melalui persiapan terlebih dahulu dan didasarkan pada kemahiran dan ketrampilan tertentu.

Adanya perbedaan perilaku pengambilan risiko yang melibatkan perilaku fisik dan sosial ini memungkinkan timbulnya kecenderungan dan konsekuensi yang sangat berbeda.

Teori Cognitive Social Learning menjelaskan perilaku ini dengan menekankan faktor sosial yang dikombinasikan dengan kecenderungann kepribadian. Artinya, kedua faktor di atas memiliki pengaruh yang lebih besar dibandingkan dengan aspek fisiologis. Lebih jelas bentuk yang ada adalah sebagai berikut : a. Adanya perbandingan sosial (social comparison). Hal ini terjadi sejak seseorang berpikir bahwa berisiko adalah baik, sehingga mereka cenderung membandingkan keputusan yang mereka buat secara individual dengan normanorma sosial. Jika seseorang berada dalam situasi kelompok, ia akan berusaha minimal mempunyai risiko yang sama atau sedikit lebih besar dari orang lain.

Contoh yang jelas untuk hal ini adalah ketika seseorang melakukan kegiatan sosial yang berisiko tertundanya rencana atau kebutuhan pribadi. Dalam hal ini seseorang tersebut mempertimbangkan bahwa tidak hanya dia sendiri yang mengorbankan kepentingan pribadi, namun hal ini juga dilakukan oleh orang lain.

b. Adanya nilai risiko dalam bentuk argumentasi-argumentasi persuasif. Penghargaan terhadap pengambil risiko membuat seseorang cenderung memilih alternatif yang berisiko daripada alternatif yang lebih aman dan cenderung hati-hati. Kecenderungan argumentasi ini membantu mempengaruhi orang untuk menjadi lebih berisiko.

Hal ini bisa dilihat dalam ajakanajakan untuk berbuat sesuatu yang membawa risiko, namun disadari sangat penting untuk dilakukan, misalnya menjadi anggota tim SAR, pemimpin organisasi, dan lain-lain.

Kedua tekanan tersebut di atas dapat terjadi secara bersamaan, terutama jika seseorang berada dalam situasi kelompok, karena anggota akan 
termotivasi oleh perbandingan dan kompetisi untuk menjadi lebih berisiko.

Berdasarkan uraian di atas, dapat disimpulkan bahwa perilaku pengambilan risiko merupakan berbagai aktivitas yang memungkinkan membawa sesuatu yang baru atau cukup berbahaya dan dapat menimbulkan kecemasan pada hampir setiap orang. Setiap individu memiliki bentuk dan alasan yang berbeda dalam melakukan tindakan pengambilan risiko dalam kehidupannya. Yang pasti, pengambilan risiko adalah sesuatu hal yang bisa dan biasa terjadi pada setiap orang.

Ada banyak faktor yang mempengaruhi perilaku pengambilan risiko seseorang, antara lain :

a. Pusat Kendali diri atau Locus of Control

Faktor kendali diri yang dimiliki individu mempengaruhinya dalam pengambilan risiko yang diambil. Bass dan Stogdill (1990) menyebutkan bahwa orang-orang yang memiliki kemampuan mengambil risiko yang tinggi adalah orang yang memiliki tipe pusat kendali (locus of control) internal. Individu dengan tipe ini merasa bahwa masa depan dan peruntungannya ditentukan oleh kemampuan, pengetahuan, dan ketrampilannya sendiri. Sebaliknya, orang-orang yang kurang berani mengambil risiko ternyata adalah tipe orang dengan pusat kendali eksternal, yang menganggap bahwa masa depan dan peruntungannya lebih banyak ditentukan oleh faktor-faktor di luar kekuasaannya, seperti nasib, atasan, teman dan dewata. b. Emosi Positif atau Positive Affect

Secara umum individu akan lebih berani mengambil risiko ketika perasaannya sangat senang daripada ketika perasaannya sedang netral, meskipun bukan berarti hal yang mustahil jika individu enggan mengambil risiko ketika suasana hatinya sedang senang (Baron \& Byrne, 1991). Keengganan mengambil risiko ini barangkali disebabkan oleh kemungkinan adanya kerugian, dan berpikir tentang hal tersebut membuat seseorang cenderung menurunkan atau bahkan menunda perasaan-perasaan positif yang dialaminya.

c. Kebutuhan akan kekuasaan atau need of power

Individu dengan kebutuhan akan kekuasaan yang tinggi cenderung ingin menyelesaikan tugas dengan risiko dan bahaya-bahaya fisik yang dibebankan padanya, dibandingkan dengan kelompok yang memiliki kebutuhan akan kekuasaan yang rendah. Meskipun demikian, individu yang mempunyai kebutuhan akan kekuasaan tinggi lebih cenderung memilih tugas-tugas dengan tingkat kesulitan sedang daripada tugas-tugas yang secara ekstrim sulit untuk dipecahkan.

\section{d. Motivasi berprestasi}

Orang-orang yang memiliki motivasi untuk sukses cenderung memilih risiko sedang, daripada resiko rendah atau terlalu tinggi. Sebaliknya orang yang takut akan kegagalan, lebih sering menghindari atau cenderung lebih memilih risiko yang rendah (Atkinson dalam Fieldman, 1999). Pada diri individu yang memiliki orientasi sukses, pemilihan akan risiko dengan tingkat sedang merupakan kompromi antara 
nilai pendorong kesuksesan pada tugas-tugas yang sulit dan kemungkinan kesuksesan pada tugas yang mudah. Dengan demikian, individu cenderung memilih tugas yang dapat dicapai secara realistis (Sorentino \& Haewitt, 1992).

e. Dorongan mencari sensasi

Individu yang memiliki dorongan mencari sensasi atau selalu mencari pengalaman sensasional, cenderung akan mengambil risiko yang tinggi. $\mathrm{Hal}$ ini dilakukan semata-mata untuk meningkatkanperasaan sensasionalnya, sehingga biasanya faktor pertimbangan secara rasional cenderung diabaikan (Levenson, 1990).

\section{f. Sifat Altruistik}

Altruisme sering diartikan sebagai perilaku yang tidak mementingkan diri sendiri dan dapat mengarah pada sikap heroisme. Sikap ini akan melibatkan proses pengambilan risiko pada diri individu. Dalam hal ini individu cenderung suka membantu kesulitan orang lain, walaupun mengandung risiko yang tinggi (Baron \& Byrne, 1991).

g. Lingkungan organisasi (kelompok). Individu dalam kelompok cenderung membuat keputusan yang lebih berisiko daripada saat individu harus memecahkan masalah secara sendiri (Stoner \& Freeman, 1989).

Berdasarkan uraian di atas, nampak bahwa banyak faktor yang menyebabkan munculnya perilaku pengambilan risiko. Faktor-faktor tersebut bisa berasal dari dalam diri maupun dari luar diri individu. Faktor dari dalam antara lain pusat kendali diri, emosi positif, kebutuhan akan kekuasaan, motivasi berprestasi, dorongan mencari sensasi dan sifat altruistik, sedangkan lingkungan adalah faktor dari luar.

\section{Dorongan mencari sensasi.}

Istilah dorongan mencari sensasi dipopulerkan oleh Zuckerman (dalam Fieldman, 1985). Menurutnya dorongan mencari sensasi merupakan sebuah sifat (trait) yang ditandai oleh kebutuhan berbagai macam sensasi dan pengalaman pengalaman yang baru, luar biasa, dan kompleks, serta kesediaan untuk mengambil risiko, baik fisik, sosial, hukum maupun finansial, untuk memperoleh pengalaman tersebut.

Dorongan mencari sensasi ada pada setiap manusia, namun berbeda tingkatannya. Sebagai suatu ciri sifat, dorongan ini bersifat menetap dan merupakan kecenderungan atau predisposisi yang tampak keluar. Teori mengenai ciri sifat kepribadian ini mengemuka setelah ditemukan adanya perbedaan individu (individual differences) yang konsisten pada taraf stimulasi dan pengaktifan tubuh dan sistem syaraf (arousal) yang optimal, yang muncul pada aktivitas-aktivitas yang dilakukan oleh manusia.

Teori arousal tentang motivasi menyebutkan bahwa dalam berperilaku individu selalu berusaha mempertahankan tingkat arousal yang dimiliki agar setaraf dengan tingkat arousal yang ideal. Individu akan merasa tidak nyaman ketika tingkat arousal-nya terlalu rendah (pada saat seseorang mengantuk atau merasa bosan) atau terlalu tinggi (ketika muncul rasa takut, cemas, atau panik yang kuat). Setiap orang memiliki taraf optimal arousal yang berbeda, yang dapat digambarkan lewat kurva $\mathbf{n}$ atau kurva $\mathbf{U}$ terbalik. Berikut ini 
adalah gambaran mengenai keterkaitan antara tingkat arousa/ dengan efisiensi kinerja :

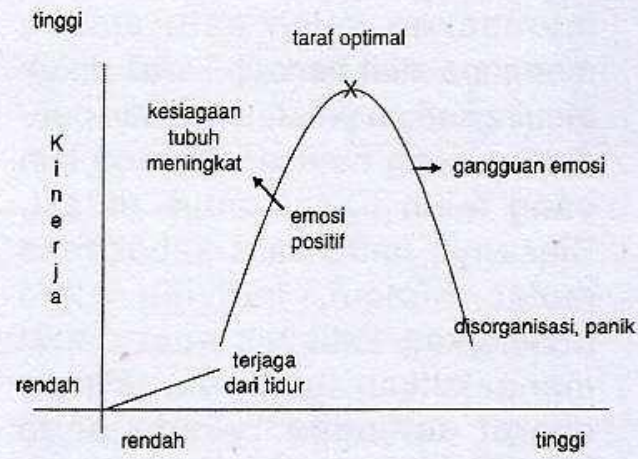

Tingkat pengaktifan tubuh dan sistem syaraf ( level of arousal)

Gambar 1: Hubungan antara tingkat arousal dengan efisiensi kinerja ( performance) (sumber: Zuckerman dalam Coon, 1989)

Pada gambar di atas nampak bahwa taraf arousal yang optimal berada di tengah-tengah interval respon organisme. Pada titik inilah terjadi kesenangan (excitement) yang paling puncak, reinforcement dan proses informasi yang paling efisien. Banyak perilaku yang dimotivasi oleh kebutuhan untuk mencapai taraf optimal ini, misalnya mengendarai kendaraan dengan kecepatan tinggi, menonton film horor, makan makanan yang pedas, naik roller coaster dan lain-lain.

Fowles, dkk. (dalam Levenson, 1990) mengidentifikasikan hal-hal yang mendasari terjadinya perilaku pengambilan risiko yang berkaitan dengan dorongan mencari sensasi. Perilaku orang yang terus menerus mencari pengalaman yang sangat menantang berkaitan dengan low arousability.
Dengan melakukan perilaku berisiko, seorang pengambil risiko mencoba meningkatkan low arousal yang dimilikinya ke tingkat optimum.

Individu dengan dorongan mencari sensasi yang tinggi akan selalu berusaha meningkatkan arousal yang dimilikinya pada tingkat yang optimal agar perasaan dan fungsifungsi tubuhnya berada dalam kondisi yang terbaik. Mereka cenderung memandang risiko sebagai suatu harga yang harus dibayar atau ditebus apabila ingin memperoleh reward dari suatu pengalaman tertentu. Sementara individu dengan dorongan mencari sensasi yang rendah tidak hanya menolak risiko tetapi juga tidak melihat adanya reward yang setara dengan risiko yang diambil. Inilah sebabnya mengapa individu pencari sensasi tinggi dan pencari sensasi rendah tidak pernah dapat saling memahami satu sama lain, sekalipun mereka suamiistri atau anak-orang tua (Zuckerman, 1994).

Dari uraian di atas dapat disimpulkan bahwa dorongan mencari sensasi adalah suatu dorongan untuk mencari stimulus yang menantang untuk mendapatkan pengalaman terhadap halhal yang baru dan luar biasa, dengan kesediaan untuk mengambil risiko atas pengalaman tersebut.

Zuckerman merumuskan empat komponen dalam dorongan mencari sensasi, yakni :

a. Mencari petualangan \& sensasi (Thrill and Adventure Seeking), yaitu keinginan untuk melakukan aktivitas fisik yang melibatkan kecepatan (speed), berbahaya (danger), sesuatu yang baru (novelty), dan 
penyimpangan gravitasi, misalnya terjun payung dan menyelam. Olahraga yang beresiko tinggi sangat disenangi karena dapat membangkitkan ketegangan dan kegembiraan besar yang tidak dapat ditimbulkan oleh kegiatan lain.

b. Mencari pengalaman (Experience Seeking), yaitu keinginan mencari pengalaman baru dengan bepergian (traveling), musik, seni, atau gaya hidup nonkonformis dengan orangorang yang cenderung sama. Seni mengandung elemen-elemen konflik, kompleksitas, ketidakpastian, sesuatu yang baru dan luar biasa, kejutan (surprise), dan ketidakharmonisan (incongruity). Individu akan terdorong untuk mengeksplorasi stimulus-stimulus yang mengandung sejumlah informasi baru.

c. Disinhibisi (Disinhibition), yakni keinginan untuk berada dalam aktivitas sosial yang bebas atau tanpa larangan. Individu sering melakukan sesuatu yang mereka tahu tidak akan disetujui oleh teman atau saudara mereka. Mereka bahkan sering melanggar komitmen jika menemukan sesuatu yang lebih menarik untuk dilakukan (Franken, 1988).

d. Mudah bosan (Boredom susceptability), yaitu tidak suka dengan pengalaman yang berulang, pekerjaan rutin, orang-orang yang mudah ditebak (predictable) dan merasa gelisah bila berada dalam suasana seperti itu. Ketika muncul kebosanan, pada umumnya individu akan mencari cara untuk membuat mereka merasa tertarik atau segera mencari aktivitas-aktivitas baru lainnya. Menambah dosis stimulan baru merupakan salah satu cara untuk meningkatkan kegembiraan dan kepuasan yang telah dialami. Hal ini merupakan salah satu alasan mengapa atlet berlatih keras untuk meningkatkan prestasinya dan pendaki gunung mencari gunung lain yang lebih tinggi untuk didaki. Biasanya pada saat kebosanan mulai muncul, individu akan melakukan aktivitas agar dapat mengaktifkan tubuh dan sistem syaraf sehingga berada pada tingkat moderat (sedang), seperti mendengarkan musik, pergi ke pesta, olah raga, berbincangbincang dengan orang lain, atau kegiatan yang lain.

Mencermati keempat aspek yang ada dalam dorongan mencari sensasi, dapat disimpulkan bahwa dorongan ini meliputi aktivitas-aktivitas fisik, sosial maupun keduanya. Belum ada penjelasan yang pasti tentang keberadaan keempat aspek ini apakah harus secara bersama-sama dimiliki oleh seorang pencari sensasi, ataukah cukup diwakili oleh salah satu aspek saja.

\section{Hubungan dorongan mencari sensasi dan perilaku pengambilan risiko pada mahasiswa. \\ Dalam perjalanan kehidupan, setiap orang dapat dipastikan akan berhadapan dengan berbagai perma- salahan. Suatu ketika permasalahan dapat bersifat ringan, sehingga untuk menghadapinya tidak memerlukan upaya atau cara yang maksimal. Dalam pengertian ini, proses pengambilan keputusan akan lebih mudah dilakukan.}


Namun tak jarang permasalahan yang berat hadir di hadapan seseorang. Pada saat itu, tak jarang dalam proses pemecahan masalah membutuhkan upaya yang berat, yang memaksanya untuk berhadapan dengan upaya pengambilan risiko.

Pada kondisi yang sama, pengambilan keputusan yang cepat dan tepat mutlak diperlukan. Antisipasi terhadap berbagai hal yang muncul sebagai konsekuensi adanya pengambilan risiko harus dimiliki. Pada individu dengan dorongan mencari sensasi yang tinggi, konsekuensi ini tidak menjadi masalah. Hal ini disebabkan individu yang bersangkutan selalu siap dengan berbagai ketidaknyamanan dan memiliki toleransi yang tinggi akan segala hal yang tidak pasti atau hal yang tidak bisa ditebak atau diprediksi.

Sementara itu orang yang memiliki dorongan mencari sensasi rendah akan memilih permasalahan yang memiliki jawaban yang pasti dan dapat diprediksi. Individu yang demikian cenderung tidak mau mengambil risiko. Sebaliknya, orang yang memiliki dorongan mencari sensasi yang tinggi akan berani menghadapi risiko dan ketidakpastian. Pengambilan risiko yang diambil pun lebih berani dibandingkan individu dengan dorongan mencari sensasi yang rendah.

Berdasarkan uraian di atas, jelas bahwa ada keterkaitan antara dorongan mencari sensasi dan perilaku pengambilan risiko pada seseorang. Dorongan mencari sensasi yang tinggi menyebabkan individu lebih berani dalam mengambil resiko.

\section{HIPOTESIS}

Hipotesis yang diajukan dalam penelitian ini adalah ada hubungan antara tingkat dorongan mencari sensasi dan perilaku pengambilan resiko pada mahasiswa. Semakin tinggi tingkat dorongan mencari sensasi yang dimiliki, makin tinggi pula perilaku pengambilan risiko.

\section{METODE PENELITIAN}

Penelitian ini menggunakan dorongan mencari sensasi sebagai variabel bebas dan perilaku pengambilan risiko sebagai variabel tergantung. Perilaku pengambilan risiko adalah bentuk perilaku yang memungkinkan individu untuk membawa suatu pengalaman yang baru atau cukup berisiko dan dapat menimbulkan kecemasan. Dalam penelitian ini peneliti menggunakan teknik eksperimen untuk mengukurnya, yakni dengan permainan gelang yang dimainkan dengan jarak tertentu (Sorrentino, 1992). Dorongan mencari sensasi adalah suatu sifat yang ditandai oleh kebutuhan berbagai macam sensasi dan pengalaman-pengalaman yang baru, luar biasa, dan kompleks. Tingkatan dalam variabel ini diukur dengan menggunakan skala yang disusun oleh peneliti. Skala ini disusun berdasarkan empat aspek, yakni dorongan mencari petualangan dan sensasi (thrill and adventure seeking), dorongan mencari pengalaman (experience seeking), disinhibisi (disinhibition), dan mudah bosan (boredom susceptability).

Subjek penelitian yang berpartisipasi dalam penelitian ini adalah para mahasiswa fakultas Psikologi Universitas Islam Indonesia yang sedang 
mengambil mata kuliah Metodologi Penelitian II sebanyak 150 orang. Dalam proses penelitian ternyata ada 88 (delapan puluh delapan) orang mahasiswa yang hadir, 9 (sembilan) orang diantaranya outliers (datanya tidak bisa dipakai). Dengan demikian jumlah subjek dalam penelitian ini 79 (tujuh puluh sembilan) orang.

Data penelitian ini diperoleh dengan dua macam cara yakni hasil pengisian skala Dorongan Mencari Sensasi untuk mendapatkan tingkatan dorongan mencari sensasi dan pelaksanaan eksperimen melempar gelang-gelang dengan jarak tertentu berdasarkan kemampuan untuk mendapatkan gambaran mengenai perilaku pengambilan risiko.

1. Eksperimen Permainan Lempar Gelang-gelang

Data tentang Perilaku Pengambilan Risiko didapatkan dari pelaksahaan eksperimen permainan lempar gelang. Permainan ini diadaptasi dari penelitian yang dilakukan oleh Sorrentino, dkk ( 1992). Dalam penelitian tersebut permainan ini dipakai untuk mengukur perilaku pengambilan risiko pada mahasiswa. Penelitian ini juga menggunakan beberapa peralatan yang relatif sama dengan penelitian Sorrentino, dkk (1992), antara lain:

- Satu buah tiang setinggi 30 (tigapuluh) $\mathrm{cm}$

- Sebuah gelang dari rotan dengan diameter $15 \mathrm{~cm}$.

Adanya tanda jarak sejauh $30 \mathrm{~cm}$ (1), $90 \mathrm{~cm} \mathrm{(2),} 180 \mathrm{~cm} \mathrm{(3),} 270$ $\mathrm{cm}(4), 360 \mathrm{~cm}(5), 450 \mathrm{~cm} \mathrm{(6),}$ $540 \mathrm{~cm}$ (7) dan $630 \mathrm{~cm}(8)$.

Setelah selesai, pada masing- masing tiang dipasang gelang rotan dengan diameter $15 \mathrm{~cm}$.

Dalam pelaksanaan eksperimen dipandu oleh eksperimenter, yang bertugas memberi instruksi dan mencatat hasil yang diperoleh. Dalam penelitian ini ada 10 (sepuluh) orang eksperimenter yang terlibat, yang terdiri atas para dosen Fakultas Psikologi Universitas Islam Indonesia (8 orang) dan Universitas Gadjah Mada (2 orang). Di samping eksperimenter penelitian ini juga melibatkan seorang kasir yang bertugas memberikan hadiah uang sesuai hasil yang dicapai oleh subjek berdasarkan catatan eksperimenter.

Dua minggu sebelum pelaksanaan eksperimen, peneliti mengumpulkan para eksperimenter untuk menjelaskan proses jalannya eksperimen dari awal hingga akhir. Pada kesempatan tersebut para eksperimenter melakukan permainan peran atau role playing dengan tujuan agar tidak terjadi perbedaan perlakuan antar eksperimenter. Prosedur eksperimen dapat dijelaskan sebagai berikut :

1. Eksperimenter siap di ruang eksperimen dengan alat permainan gelang, tiang, berbagai variasi jarak lempar yang sudah ditandai, dan tabel untuk mencatat hasil pengambilan risiko.

2. Peserta mengikuti jalannya eksperimen secara individual.

3. Setelah mencatat nama dan nomor mahasiswa, eksperimenter memberikan instruksi sebagai berikut : 
Berikut ini adalah permainan gelang untuk mengetahui koordinasi visual motorik anda. Tugas anda adalah memasukkan gelang pada tiang dengan jarak tertentu. Ada 8 (delapan) variasi jarak, yang berkisar antara $30 \mathrm{~cm}$ sampai dengan $6,30 \mathrm{~m}$, yang ditunjukkan dengan garis melintang. Silakan anda berlatih memasukkan gelang yang jaraknya ditentukan secara random dengan menggunakan kupon undian yang anda pilih.

4. Eksperimenter memberikan gulungan kertas undian yang bertuliskan angka 1-8 yang menunjukkan variasi jarak. Setiap jarak, subjek diberi kesempatan satu kali. Eksperimenter mencatat berhasil atau tidaknya subjek dalam memasukkan gelang (berdasar jarak) dengan memberi tanda ( $V$ ) jika berhasil dan $(X)$ jika gagal pada lembar tabel kolom pertama.
5. Selesai latihan, eksperimenter memberikan instruksi :

Sekarang saya ingin anda membuat perkiraan keberhasilan apabila anda diberi kesempatan melempar sebanyak seratus kali untuk setiap jarak.

Eksperimenter mencatat setiap jawaban subjek pada lembar tabel kolom kedua. Subjek boleh melihat hasil latihan yang telah dicatat oleh eksperimenter pada waktu latihan.

6. Seusai subjek menyebutkan perkiraan keberhasilan dan dicatat dalam tabel RST, eksperimenter meneruskan eksperimen dengan instruksi:

Saya menawarkan hadiah uang kepada anda apabila berhasil memasukkan gelang pada tiang, dengan memilih jarak pada tabel sebagai berikut (sambil menunjukkan tabel uang):

Tabel 1. Tabel uang yang diterima berdasar jarak

\begin{tabular}{|c|c|c|}
\hline Jarak & Tiap 1 X masuk & 10 X \\
\hline 1 & $\mathrm{Rp} 100$ & $\mathrm{Rp} 1000$ \\
\hline 2 & $\mathrm{Rp} 300$ & $\mathrm{Rp} 3000$ \\
\hline 3 & $\mathrm{Rp} 600$ & $\mathrm{Rp} 6000$ \\
\hline 4 & $\mathrm{Rp} 900$ & $\mathrm{Rp} 9000$ \\
\hline 5 & $\mathrm{Rp} 1200$ & $\mathrm{Rp} 12000$ \\
\hline 6 & $\mathrm{Rp} 1500$ & $\mathrm{Rp} 15000$ \\
\hline 7 & $\mathrm{Rp} 1800$ & $\mathrm{Rp} 18000$ \\
\hline 8 & $\mathrm{Rp} 2100$ & $\mathrm{Rp} 21000$ \\
\hline
\end{tabular}


Silakan anda pilih satu jarak dari delapan jarak yang disediakan, dan lakukan 10 (sepuluh) kali lemparan.

7. Setelah subjek menentukan jarak, eksperimenter mencatat pada kolom ketiga dalam tabel RST dan diberi tanda (V) bila berhasil dan $(X)$ bila gagal.

8. Eksperimenter menanyakan alasan pemilihan jarak dan menulis jawaban subjek di bawah tabel.

9. Eksperimenter menulis jarak dan hasil dalam kertas kupon yang disediakan.

10. Subjek dipersilakan menemui kasir sambil membawa kupon untuk ditukar dengan uang.

Para eksperimenter diminta untuk memberi instruksi dan perlakuan yang sama kepada setiap subjek, sehingga tidak ada perbedaan perlakuan yang diterima oleh subjek.

2. Skala Dorongan Mencari Sensasi (Skala SS)

Skala Dorongan Mencari Sensasi disusun berdasarkan empat aspek yang mendasari dorongan mencari sensasi ada dalam variabel ini, yakni dorongan mencari petualangan dan sensasi (thrill and adventure seeking), dorongan mencari pengalaman (experience seeking), disinhibisi / keinginan untuk berada dalam aktivitas sosial yang bebas (disinhibition), dan mudah bosan (boredom susceptability). Koefisien reliabilitas alat ukur ini sebesar 0,8464 .

Penelitian dilaksanakan pada tanggal 7 Mei 2001 bertempat di fakul- tas Psikologi Universitas Islam Indonesia. Satu minggu sebelum pelaksanaan, peneliti memberikan pengumuman tentang rencana penelitian yang ditempel di papan pengumuman. Peneliti mengajak mahasiswa yang ingin ikut berpartisipasi sebagai subjek penelitian dengan mengambil blangko pernyataan persetujuan di meja peneliti dan mengisinya sebelum tanggal 7 Mei 2001.

Dalam blangko tersebut peneliti menjelaskan bahwa penelitian ini bertujuan untuk melihat kemampuan visual-motorik mahasiswa dan tidak ada risiko fisik maupun psikologis yang akan mereka terima. Di samping itu peneliti berjanji memberikan bonus sebesar 10 poin untuk mahasiswa yang tengah mengambil mata kuliah Metodologi Penelitian II, yakni suatu mata kuliah yang saat itu sedang peneliti ampu, untuk memberikan kesempatan mahasiswa mengalami proses penelitian eksperimental.

Antusias mahasiswa cukup baik, terbukti dengan banyaknya jumlah pendaftar yang mencapai 90 (sembilan puluh) orang. Berdasar ka n pada subjek penelitian sejumlah 8 9 orang. Pada masing-masing kelas dipasang tiang dari kayu setinggi 30 $\mathrm{cm}$ dan melekatkannya dengan isolasi (agar tidak mudah goyah dan lepas), kemudian memberi tanda jarak sejauh $30 \mathrm{~cm}(1), 90 \mathrm{~cm}(2), 180 \mathrm{~cm}$ (3), $270 \mathrm{~cm}(4), 360 \mathrm{~cm}(5), 450 \mathrm{~cm}$ (6), $540 \mathrm{~cm}$ (7) dan $630 \mathrm{~cm}$ (8). Setelah selesai, pada masing-masing tiang dipasang gelang rotan dengan diameter $15 \mathrm{~cm}$.

Hari pelaksanaan penelitian sengaja digunakan hari libur Nasional, agar tidak mengganggu kegiatan 
mahasiswa, para karyawan dan dosen yang terlibat penelitian, di samping situasi kampus relatif tenang sehingga tidak mencemari hasil penelitian. Semua subjek dikumpulkan terlebih dahulu dalam satu ruang kuliah besar, untuk mendapatkan penjelasan tentang eksperimen yang akan mereka alami. Hal pertama yang dilakukan setelah itu adalah mengambil data dorongan mencari sensasi yang dipandu oleh assisten peneliti. Ketika subjek mengerjakan angket dorongan mencari sensasi, peneliti membagi lembar instruksi, lembar hasil RST (perilaku pengambilan risiko), nomor undian dan kupon kepada para eksperimenter sambil mengecek kembali pemahaman mereka atas instruksi eksperimen. Setelah selesai, peneliti mempersilakan para eksperimenter untuk masuk ke dalam ruang-ruang kelas yang dipakai untuk pelaksanaan eksperimen.

Begitu subjek selesai mengerjakan angket dorongan mencari sensasi, mereka diminta untuk masuk ke dalam ruang eksperimen satu per satu, sehingga tiap subjek menjalani proses eksperimen tanpa dilihat oleh subjek lain. Hal ini untuk menghindari efek keterlibatan orang lain dalam proses perlakuan. Sambil menunggu giliran, subjek dipersilakan menikmati hidangan (snack) yang telah disediakan.

Seusai subjek menjalani eksperimen, maka dia harus segera menemui kasir yang telah siap dengan uang, untuk menukar kupon yang berisi hasil eksperimen (yang ditulis oleh eksperimenter) tanpa kembali ke kelas lagi. Hal ini untuk menghindari subjek lain yang belum mendapat giliran masuk ke ruang eksperimen akan mengetahui proses jalannya eksperimen, sehingga mengganggu hasil eksperimen (tidak murni lagi).

Setelah semua subjek menyerahkan kupon dan ditukar dengan uang oleh kasir, peneliti kemudian mencocokkan hasil catatan eksperimenter dengan uang yang telah dikeluarkan oleh kasir, untuk menghindari adanya subjek yang dirugikan. Ketika semua sudah sesuai, maka proses penelitian telah selesai dilaksanakan.

Data yang dihasilkan dalam penelitian ini dianalisis dengan menggunakan teknik product moment. Dalam proses analisis menggunakan Program SPSS for Windows versi 10.

\section{HASIL PENELITIAN}

1. Hasil Deskriptif Variabel Penelitian

\begin{tabular}{|c|l|r|r|r|c|}
\hline No & \multicolumn{1}{|c|}{ Variabel } & $\begin{array}{r}\text { Rerata } \\
\text { Empirik }\end{array}$ & $\begin{array}{c}\text { Standard } \\
\text { Deviasi }\end{array}$ & $\begin{array}{c}\text { Rerata } \\
\text { Hipotetik }\end{array}$ & Kategorisasi \\
\hline 1 & $\begin{array}{l}\text { Perilaku Pengambilan } \\
\text { Risiko }\end{array}$ & 24,19 & 20,79 & 50,00 & Rendah \\
\hline 2 & $\begin{array}{l}\text { Dorongan mencari } \\
\text { sensasi }\end{array}$ & 53,44 & 7,05 & 62,50 & Rendah \\
\hline
\end{tabular}


Melihat hasil yang tertera dalam tabel di atas tampak bahwa pada semua variabel penelitian, kondisi subjek penelitian berada dalam kategori rendah, yakni dalam hal perilaku pengambilan risiko dan dorongan mencari sensasi.

\section{Hasil Uji Hipotesis}

Berdasarkan analisis data dengan teknik product moment ditemukan korelasi dorongan mencari sensasi dengan perilaku pengambilan risiko memiliki $r=0,226$ dan $p=0,045$. Berdasarkan nilai beta tersebut dapat disimpulkan bahwa dorongan mencari sensasi memiliki hubungan terhadap perilaku pengambilan risiko.

\section{PEMBAHASAN}

Pengujian hipotesis dalam penelitian ini membuktikan adanya hubungan dorongan mencari sensasi terhadap perilaku pengambilan risiko. $\mathrm{Hal}$ ini menunjukkan bahwa untuk mengambil risiko seseorang perlu memiliki kesiapan untuk menerima tantangan dan hal-hal baru, yang merupakan salah satu aspek dalam dorongan mencari sensasi. Setelah dicermati dari nilai korelasi hubungan yang ada, dapat diketahui bahwa dorongan mencari sensasi memberikan sumbangan $5 \%$ untuk memunculkan perilaku pengambilan risiko. Kecilnya angka sumbangan variabel tersebut terhadap perilaku pengambilan risiko menunjukkan besarnya sumbangan variabel lain (95\%) yang tidak diteliti. Dari kajian pustaka bisa disebutkan variabel-variabel tersebut, yakni pusat kendali diri, emosi positif, sifat altruistik dan lingkungan.
Berdasarkan hasil penelitian secara deskriptif, nampak bahwa subjek penelitian memiliki tingkat dorongan mencari sensasi dan perilaku pengambilan risiko yang rendah. Hal ini menarik untuk dikaji lebih jauh, karena berkaitan erat dengan upaya penyiapan sosok SDM yang berkualitas.

Mahasiswa selaku pemegang tongkat estafeta kepemimpinan di masa depan, mestinya memiliki kemampuan untuk mengambil risiko secara memadai. Dalam penelitian ini tampak bahwa subjek penelitian, yang notabene mahasiswa, ternyata memiliki nilai rendah dalam hal dorongan mencari sensasi, dan pengambilan risiko. Rendahnya nilai dalam dorongan mencari sensasi menunjukkan bahwa subjek cenderung kurang terbiasa untuk mencari pengalamanpengalaman baru. Subjek cenderung mengambil posisi untuk menekuni halhal yang biasa dan

lebih memberikan rasa aman.

Dalam simulasi dengan eksperimen yang dilakukan selama proses penelitian menunjukkan bahwa subjek lebih banyak mengambil jarak melempar yang dirasakan paling mudah dilakukannya. Hal ini terjadi setelah subjek mencoba pertama dan melakukan hal sama ketika mendapatkan kesempatan kembali. Menurut subjek, pilihan jarak aman tersebut merupakan hal yang harus diambil. Rasa ingin tahu dan keinginan untuk mencoba hal baru, dalam kasus ini, tidak tampak. Padahal, menurut Zuckerman (1994), mencoba pengalaman baru dan rasa ingin tahu merupakan sesuatu yang penting dalam hal ini. Tampaknya ada 
kecenderungan perasaan takut salah, takut gagal, dan takut kecewa pada diri para subjek. Hal ini tampak dominan dalam penelitian ini.

Dengan tingkat dorongan mencari sensasi yang rendah seperti itu, maka wajar bila dalam pross pengambilan risikonya pun tidak tinggi. Dari 79 subjek penelitian, hanya sekitar 18 orang yang berani mengambil risiko sedang ke tinggi. Hal ini menunjukkan bahwa sebagian besar subjek merasa bahwa risiko belum dianggap sebagai konsekuensi atas tantangan yang diberikan. Kondisi ini mendukung sebuah hasil penelitian yang menggambarkan bahwa kelompok mahasiswa yang diteliti cenderung kurang berani mengambil risiko.

Rendahnya perilaku pengambilan risiko ini menunjukkan bahwa subjek cenderung menolak pengalaman dengan stimulasi yang tinggi, yang disebabkan oleh tingkat kecemasan yang tinggi (Levenson, 1990). Hal ini nampak sekali dari proses eksperimen yang terjadi. Dalam proses penelitian, $80 \%$ subjek penelitian memiliki perilaku pengambilan risiko dengan taraf rendah (bersekor 0 sampai dengan 0.33 ). Mereka cenderung menghindar dari risiko dengan memilih lemparan gelang yang sebelumnya diprediksikan $75-100 \%$ berhasil. Dengan demikian maka sekor perilaku pengambilan risikonya rendah, artinya subjek tidak mau berisiko gagal dalam pelemparan gelang yang akan dilakukannya.

Hasil lain yang penting untuk dibahas dan dikaji secara lebih mendalam adalah korelasi antara dorongan mencari sensasi dan perilaku pengambilan risiko. Berdasarkan penelitian menunjukkan bahwa korelasi antar keduanya ada dan signifikan. Hal itu berarti bahwa dorongan mencari sensasi berhubungan dengan perilaku pengambilan risiko. Apabila dorongan mencari sensasi rendah, maka perilaku pengambilan risiko rendah. Sebaliknya apabila dorongan mencari sensasi tinggi, maka perilaku pengambilan risiko tinggi.

\section{KESIMPULAN DAN SARAN}

Berdasarkan hasil penelitian yang telah dilakukan, dapat disimpulkan hal-hal sebagai berikut :

1. Ada hubungan yang positif antara dorongan mencari sensasi dan perilaku pengambilan risiko pada mahasiswa. Semakin tinggi tingkat dorongan mencari sensasi yang dimiliki, makin tinggi pula perilaku pengambilan risikonya.

2. Subjek dalam penelitian ini memiliki tingkat dorongan mencari sensasi dan perilaku pengambilan risiko yang rendah.

Setelah mencermati hasil penelitian, penyusun merasa perlu memberikan saran kepada berbagai pihak yang terkait, antara lain :

1. Mahasiswa

Sebagai calon pemimpin bangsa di masa depan, hendaknya mulai dari sekarang mempersiapkan diri derigan senantiasa melakukan hal-hal positif yang menantang. Mahasiswa juga disarankan untuk tidak cepat puas dengan prestasi yang dicapai, sehingga selalu berusaha untuk mencapai yang lebih baik secara terus-menerus. 
2. Perguruan Tinggi

Sebagai institusi yang paling bertanggung jawab dalam menyiapkan mahasiswa menjadi generasi penerus bangsa yang berkualitas, peran Perguruan Tinggi sangatlah besar. Mahasiswa perlu mendapatkan kesempatan untuk dapat mengembangkan dirinya, dengan program-program yang menantang baik di bidang akademik maupun non akademik.

3. Peneliti selanjutnya

Hasil penelitian masih sangat terbatas, oleh karena itu disarankan untuk peneliti yang tertarik pada bidang yang sama, menambah variabelvariabel lain yang relevan, seperti aspek konsep diri dan kecemasan.

\section{DAFTAR PUSTAKA}

Atkinson, J.W. 1985 . Motives in Fantacy, Action and Society. New York: D. Van Nostrand Company inc

Baron, R.A. \& Byrne. D. 1991. Social Psychology: Understanding Human Interaction. New York: Allyn \& Beacon

Bass, B. M. \& Stogdill. 1990. Handbook of Leadership: Theory, Research \& Management Application, $3^{\text {th }}$ Edition. New York: The Press

Feldman, R.S. 1985. Social Psychology: Theories, Research, Application. New York: Mc Graw Hill
Franken, R.E. 1988. Human Motivation. ( $2^{\text {nd }}$.ed.) California Brooks / Cole Publishing Company

Haditono, S. R. 1984. Psikologi Perkembangan: Materi Dasar Pendidikan Program Bimbingan dan Konseling di Perguruan Tinggi. Makalah. Yogyakarta: Fakultas Psikologi Universitas Gadjah Mada

Hastjarjo, T. D. 1991. Pendekatan Psikofisika dan Kognitif Terhadap Tingkah Laku Memilih. Makalah. Yogyakarta: Fakultas Psikologi UGM.

Larasati, A.B. 1993. Risk Taking Behavior. Makalah. Seminar Sehari "Manajemen Risiko" dari Petualangan sampai Dunia Kerja. Yogyakarta: Fakultas Psikologi Universitas Gadjah Mada

Levenson, M.R. 1990. Risk Taking And Personality. Journal of Personality and Social Psychology, 58, 6, 1073 1080

Slovic, P., Fischhoff, B. Dan Lichtenstein, S. 1987. Taking Care : Understanding and Encouraging Self-Protective Behavior. New York : Cambridge Univ. Press

Smith, R.E. , Ptacek, J.T \& Smoll, F.L, 1992. Sensation Seeking, Stress 
and Adolescent Injuries: A Test of Stress - Buffering, Risk Taking and Coping Skills Hypothesis. Joumal of Personality and Social Psychology, 62. 6. $1016-1024$

Sorentino, R.M. \& Hewitt, E.C. 1992 Risk Taking in Games Chance and Skill Informational and Effective Influence on Choice Behavior. Joumal of Personality and Social Psychology, 62, 3, 522 $-533$

Stoner, J.A.F. , \& Freeman, R.E. 1989. Management $4^{\text {th }}$ Edition.
Englewood Cliffs, New Jersey: Prentice Hall International.

Zuckerman, M. , Carrol, E.N. , \& Vogel, W.H. 1982. A Test of the Optimal Level of Arousal of Sensation Seeking. Journal of Personality and Social Psychology. 41, 3. $572-575$

Zuckerman, M. 1994. Behavior Expressions and Biosocial Bayes of Sensation Seeking. New York: Cambridge University Press 